\title{
Managing the development of training of competitive professionals in vocational educational institutions
}

\author{
Larisa Sergeeva ${ }^{1, *}$, and Tatiana Stoychik ${ }^{2}$ \\ ${ }^{1}$ University of Management Education, 52-A Sichovyh Striltsiv Str., Kyiv, 04053, Ukraine \\ ${ }^{2}$ Kryvyi Rih Professional Mining and Technology Lyceum, 1 Elistynska Str., Kryvyi Rih, 50053, Ukraine
}

\begin{abstract}
Significant transformation processes in Ukraine, inspired by globalization, require a rethinking of educational goals, objectives, and educational imperatives. Within the educational process in vocational (vocational-technical) educational institutions, the training system is forced to take into account the global context of actions and consequences in the preparation of a competitive specialist. The purpose of this article is to analyze the current state of development of vocational (vocational-technical) education in Ukraine and the network of institutions of vocational (vocational-technical) education; identifying factors that affect the quality of training of a competitive specialist and controversies that need to be resolved in the training of professionals. To analyze the current state of preparation, a set of theoretical and empirical methods was used, with the help of which a number of problems that inhibit the process of ensuring the quality of training of a competitive specialist were identified. In order to study the current state of preparation, a set of questionnaires was developed and, within the framework of a pedagogical experiment, questionnaires were conducted among entrants, educators, graduates, pedagogical workers, heads of institutions of vocational (vocational-technical) education in the regions of Ukraine and employers, and the results of the questionnaire were analyzed.
\end{abstract}

\section{Introduction}

The global market over the past two decades has given rise to a series of negative social phenomena that characterized "wild" capitalism until the middle of the twentieth century: sharp differentiation of incomes, the formation of centers of poverty and hunger, and the undermining of social security systems. Low wages, alienation and marginalization are seen as a direct consequence of putting into practice the logic of the global free market.

In the context of the challenges of globalization, which actualize the search for new paradigms of social development, the problems of professional development of the individual, development of his creative potential, constant self-improvement and vocational training throughout life are of particular importance. The problems of professional development in the period of complex transformations of the labor sphere of modern society are of particular importance. This is due to changes in the value-meaning self-actualization of the individual and deformation of its formation in the conditions of increasing requirements for professional mobility and competitiveness of the specialist [1].

The Ukrainian system of vocational (technical and vocational) education (herein after referred to as V(VT)E has faced a number of challenges, first of all: there is a discrepancy between the quality and directions of vocational training, the levels of qualification of $\mathrm{V}(\mathrm{VT}) \mathrm{E}$ applicants on labor market needs and personality demands; low level of prestige of working professions and professional qualifications $[2, \quad$ p. 2$]$; threatening insufficient level of quality of V(VT)E, mobility and competitiveness of graduates of institutions of vocational (vocational-technical) education (herein after - V(VT)E; shortage of qualified personnel, lack of qualification level to the real needs of the labor market; ensuring availability of V(VT)E, degree of obtaining professional qualifications; outdated material and technical base of $\mathrm{V}(\mathrm{VT}) \mathrm{E}$; the need to expand the professional competencies of specialists; new requirements for the content of education and training process.

Content education requires a holistic system of cultural content. This system should cover the balanced development of the mental, emotional, value, volitional and physical spheres [3].

The challenges are due to the following factors: centralized and bureaucratized system of governance in the area of V(VT)E; insufficient amount of funding for $\mathrm{V}(\mathrm{VT}) \mathrm{E}$; low level of wages of pedagogical and other employees of V(VT)E; lack of co-operation between the $\mathrm{V}(\mathrm{VT}) \mathrm{E}$ with employers and business partners; lack of data on the state of the labor market; the imperfection of the

\footnotetext{
*Corresponding author: 1ase2508@gmail.com
} 
vocational guidance and career counseling system for young people and adults [4].

In the process of training highly qualified specialists, there are contradictions that need to be resolved, in particular, between: the need for training of highly qualified specialists and the existing system of education and scientific and methodological support in the educational process; the need to train competitive professionals and the existing V(VT)E system, which does not adequately ensure the mobility and competitiveness of professionals in the labor market; personal and professional development of the specialist in the conditions of the educational institution and insufficient opportunities of this aspect in his future competitiveness. It should be added that a competitive specialist is a subject of professional activity, which achieves the best performance in competitive working conditions due to the maximum integration of the competences required for this purpose [5, p. 7]. It is competition that acts as a specific situation, a phenomenon in which the competitiveness of any subject is formed and developed on the basis of the psychological interaction of the participants in the production process.

According to the analysis of scientific works, in recent years scientists have increasingly raised the problem of the competitiveness of the specialist and is often considered in the pedagogical aspect associated with the formation and management of the process of becoming a person in the process of professional training (Alexander G. Romanovsky [6], Sergey V. Smirnov [7]), revealing the essence of future specialists' competitiveness (Lyudmila A. Dudko [8], Elena L. Kholodtseva [9], Sergey M. Shyrokobokov [10], Rais A. Fathutdinov [11] and other.), structure and characteristics of competitive personality traits (Tatiana Y. Andriyako [12], Igor Ansoff [13], Evgeniy O. Klimov [14], Larisa M. Mitina [15] Tatiana A. Slivina [16], Olena A. Fil [17] and others), features of development of competitiveness of future specialists of different specialties in the process of vocational training in higher education (Irina P. Sarattseva [18], Svetlana O. Hazova [19], Andy Adcroft [20], Abrahim Bakar [21], Rassa Viederyte [22] and others).

In pedagogy, according to the definitions of scientists in different fields, the concept of a specialist's competitiveness must be interpreted as a specialist's ability to compete, that is, his or her corresponding competencies and personal preferences that allow him / her to win the competition.

The development of competitiveness is of a systemic nature and requires the creation of certain organizational and pedagogical conditions, educational and information environment in which the educational process takes place, educational and production activities that create the conditions for personal and professional formation of personality.

Developing the competitiveness of the future specialist is a complex, step-by-step, multi-faceted process that must take into account the individual's experience of creative professional activity and experience of constructive professional communication, that is, modeling a competitive educational environment that guarantees the quality of professions.

In view of the above, the purpose of the article is to analyze the current state of the balanced development of V(VT)E; identification of components that affect the quality of vocational training and education of a competitive specialist.

\section{Research methodology}

According to the goal, a set of interrelated research methods has been applied. Theoretical methods: systematic analysis of pedagogical and methodological literature, aimed at studying the current state of the problem of research, which made it possible to reveal the concept of "effectiveness of the activities of V(VT)E" and identify its main components. Based on the study of materials related to the concept of quality of education, such as "Regulation of the quality of education as a philosophical and educational problem" (V. G. Viktorov), "Quality of education. Resulting qualities of education. Methodical provision of the state standard of initial vocational education" (V. G. Kazakov), "Management of the development of a professional educational institution: praxeological foundations" (L. M. Sergeeva et al.), "Professional development. Encyclopedia of Education" (V. V. Rybalka), "Theoretical and methodological foundations of managing the development of a vocational school" (L. M. Sergeeva) have clarified the essence of the concept of "quality of education" and defined the basic approaches to determining quality.

Empirical methods: interviews and questionnaires of employers; testing of GV(VT)E applicants for the purpose of socio-psychological selection for training; questionnaire of pedagogical staff (teachers and practice leaders) questionnaire developed by the authors; methods of mathematical statistics: in order to verify the accuracy of the data, quantitative and qualitative processing of the obtained results by means of computer equipment was carried out.

It was interviewed: 14 institutions, 9 of which are $\mathrm{V}(\mathrm{VT}) \mathrm{E}$ and 5 institutions of professional higher education; 175 participants; 175 educators; 86 employers; 84 management and 280 teaching staff; 548 graduates of the V(VT)E about ten districts of Ukraine.

\section{Results and discussion}

At the beginning of the study, we considered it necessary to consider the overall state of development of V(VT)E in Ukraine.

As of 01.01.2018, there were $754 \mathrm{GV}(\mathrm{VT}) \mathrm{Is}$ in Ukraine. Compared to 1990, the network of institutions decreased by 492 institutions (table 1, fig. 1) [23].

An important problem that today has a negative impact on reducing the contingent in the country's GV(VT)E is 
that it is perceived as a panacea for social inclusion and integration of vulnerable populations. But this is not about competitiveness in the global marketplace, lifelong learning and innovation.

Table 1. Network GV(VT)E and the Dynamics of the Contingent of Educators in Ukraine

\begin{tabular}{|c|c|c|c|c|}
\hline Indicator & $\begin{array}{c}\text { Amount of } \\
\mathrm{GV}(\mathrm{VT}) \mathrm{E}\end{array}$ & $\begin{array}{c}\text { Reduction } \\
\text { of } \\
\mathrm{GV}(\mathrm{VT}) \mathrm{E}\end{array}$ & $\begin{array}{c}\text { Average } \\
\text { Filling } \\
\mathrm{GV}(\mathrm{VT}) \mathrm{E}, \\
\text { persons }\end{array}$ & $\begin{array}{c}\text { Reduction of } \\
\text { the contingent, } \\
\text { persons }\end{array}$ \\
\hline 1990 & 1246 & & 516 & \\
\hline 1995 & 1179 & -67 & 471 & -45 \\
\hline 2000 & 970 & -209 & 541 & +72 \\
\hline 2005 & 1023 & +53 & 485 & -56 \\
\hline 2010 & 976 & -47 & 444 & -41 \\
\hline 2014 & 814 & -162 & 388 & -56 \\
\hline 2015 & 798 & -16 & 381 & -7 \\
\hline 2016 & 787 & -11 & 363 & -18 \\
\hline 2017 & 756 & -31 & 356 & -7 \\
\hline 2018 & 754 & -2 & 253 & -106 \\
\hline
\end{tabular}

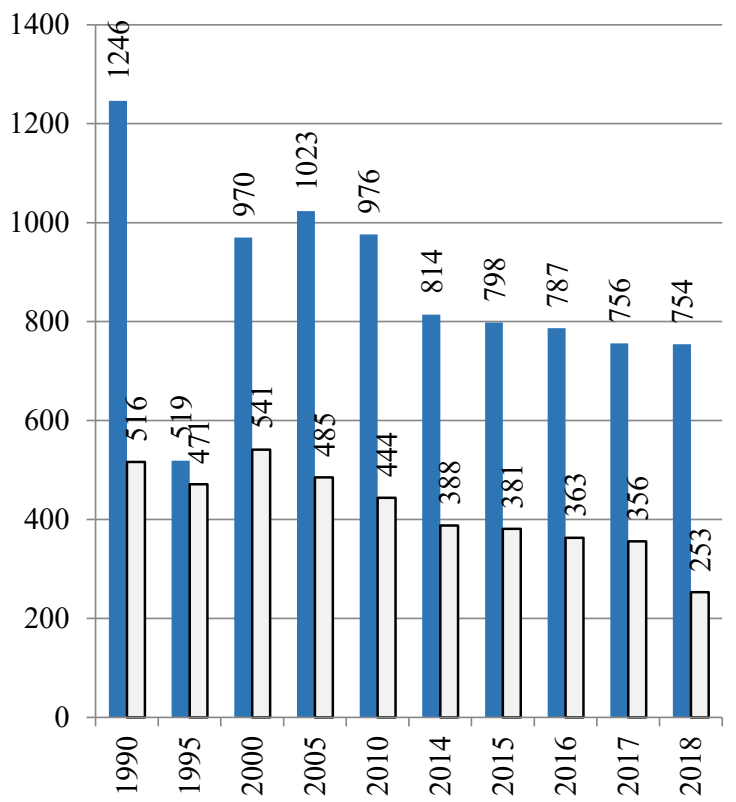

$\square$ Number of GVE $\square$ Average occupancy, persons

Fig. 1. General Vocational(VT)Education Network and the Dynamics of the Contingent of Educators in Ukraine.

In many countries, vocational education is considered a vital component of improving production efficiency, stimulating the development and competitiveness of the economy, reducing unemployment, as well as a tool to improve the situation of the poor.

The Europe 2020 Strategy: Strategies for Intellectual and Balanced Development Promoting Community Engagement prioritize three interconnected elements of the classic concept of balanced development: intellectual development: that is, the development of a knowledge and innovation based economy; balanced development, that is, development of the economy, with efficient use of resources, and development that promotes social activity: that is, the development of an economy with a high level of employment [24].

According to Eurostat, almost half of all second-year secondary school graduates in 28 European Union countries have gone through vocational training programs. And in the case of the Republic of Austria, the Czech Republic, the Republic of Croatia and the Finnish Republic, this proportion was $70 \%$ and above.

In Ukraine, the contingent of GV(VT)E applicants for 2018 is 253.9 thousand people, including: on the basis of complete general secondary education (11 classes) 62.0 thousand $(24.5 \%)$, on the basis of basic secondary education ( 9 classes) - 178.1 thousand people $(70.1 \%)$, on the basis of incomplete basic secondary education (up to 9 classes) - 2.2 thousand people $(0.5 \%)$, trainees 12.5 thousand persons (4.9\%) (fig. 2) [23].

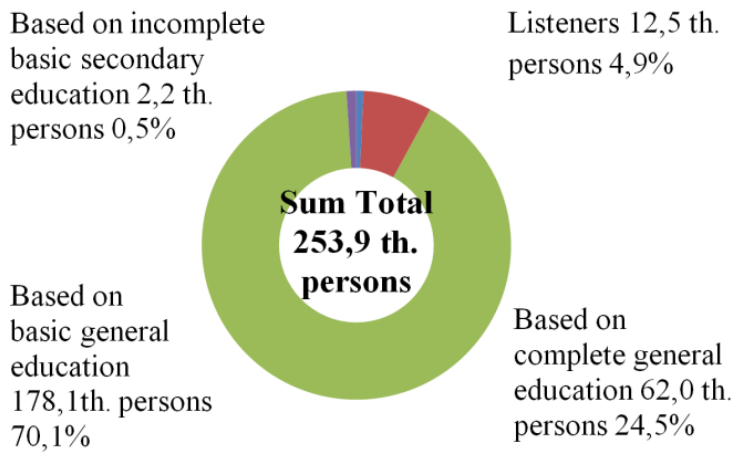

Fig. 2. Contingent of Educators and Listeners as of 01.01.2018.

The analysis indicates a significant reduction in the contingent of the GV(VT)E. There is a tendency of not fulfilling the plan of the order for training of qualified specialists, so in 2016 at the planned indicators 127 thousand persons $(100 \%)$ were enrolled for training of 118,5 thousand persons $(93 \%)$, thus the regional order for 112,5 was not fulfilled thousand people, state -6 thousand people. The formation of a contingent of GV(VT)E on a residual principle significantly affects the quality of education of the educational service provider. According to V. G. Viktorov, the quality of education is a category that by its nature reflects various aspects of the educational process - philosophical, social, pedagogical, demographic, economic and others [25, p. 8].

According to United Nations Secretary-General Ban $\mathrm{Ki}$-moon, quality education is not just a content delivery system; rather, it is a system designed to help job seekers fully unlock their potential and enter society as full and productive citizens ready to lead the future [26].

The quality of education is defined as the basis for the political, economic independence of the state, as a major factor in ensuring the competitiveness of both the individual graduate and the country as a whole. There are 
two main approaches to defining the essence of the quality of education, which is considered from the point of view: - achievement of certain norms, standards, goals and needs (individuals, societies, states). This approach is based on establishing a match between the planned and achieved educational quality indicators, but does not focus on identifying the reasons for the violation of this compliance, finding out the factors of influence, measuring their weight, intensity, etc., which does not allow to develop an effective management strategy aimed at improving quality of education and development of educational institution; - modern theory and practice of quality management as a theoretical category. Within this approach, the quality of education is a clearly defined dynamic object that can change in the right direction in accordance with managerial influence [27, p. 34].

Therefore, the quality of education can be interpreted as: the social ideal of human education; as a result of her educational activities; as a process of organizing education and training; as a criterion for quality educational activities.

The quality of educational activity characterizes the level of organization of the educational process in an educational institution, provided it meets the standards of $\mathrm{V}(\mathrm{VT}) \mathrm{E}$ and the professional development of future specialists. The purpose of this process is to develop an employee's professional culture, which is manifested in a high level of professional education, competence and skill, in realizing them the value of their profession and themselves as a professional, dedication to their profession, achieving on this basis socially and personally significant creative results [28, p. 733].

It is important to include the notion of "efficiency" in the "quality of education" characteristic and be considered as a criterion for evaluating the activities of the teaching staff in any field, including management. Ensuring high management effectiveness is part of the overall problem of enhancing the effectiveness of GV(VT)E activities. The effectiveness of V(VT)E can be determined in the areas that should be measured, plausible and predetermined in the clear results of their achievement, in particular: the content of vocational training and its comprehensive methodological support; availability of V(VT)E worlds; professional success of graduates; personnel potential of the educational institution; material and technical base; financing [27, p.5].

The results of the level of quality of education and its effectiveness are likely to be ensured within the framework of pedagogical research. The leading method of pedagogical research is experiment. In science, an experiment is understood as a way of studying phenomena in regulated conditions, which allows you to reproduce, observe and record phenomena by hardware methods or by using appropriate scientific documentation. In an experiment, any phenomenon can be investigated under different conditions, repeated several times under the same and changed circumstances. The essence of the experimental method is that it is aimed at the study of cause and effect relations between the objects studied, which allows you to truly master the laws of pedagogy for practical purposes [29, p. 13].

The limits of using pedagogical experiment as a method of scientific cognition in pedagogy are considerably broadened due to the fact that the training of future specialists in the $\mathrm{GV}(\mathrm{VT}) \mathrm{E}$ combines all the necessary components of education. The process of professional training of specialists takes place both in training and in production conditions. The experiment helps to identify the links between theoretical and industrial learning, the quality of the acquired knowledge, skills and abilities, to establish the ambiguity and complexity of actions of many pedagogical factors. This, of course, increases the possibilities of pedagogical experiment before other methods.

The tasks of further improvement of pedagogical science, especially in the field of $\mathrm{V}(\mathrm{VT}) \mathrm{E}$, require from a pedagogical experiment multifaceted and at the same time - holistic consideration of the object of study, systemstructural analysis of interacting factors.

I stage the experiment stage in our study was aimed at substantiating the choice of the number of respondents, determining the actual level of quality of training of competitive specialists (incoming diagnosis).

II stage - approbation of the results of the research of the quality management system of training of competitive specialists.

III stage - determining the final level of competitiveness of the educational institution as a component of the system of management of the development of GV(VT)E (initial diagnosis). Comparison and statistical processing of the results obtained.

The ascertainment (stage I) of the pedagogical experiment is such that it establishes only the real state of affairs in the process of research. The purpose of the ascertaining stage of the pedagogical experiment was to determine the actual level of quality of the training of competitive specialists in the conditions of GV(VT)E.

14 institutions were involved in the ascertaining stage of the pedagogical experiment, 9 of which were GV(VT)E and 5 professional higher education; 175 participants; 175 educators; 86 employers; 84 management and 280 teaching staff; 548 graduates of the GV(VT)E about 10 regions of Ukraine, including:

GV(VT)E: Kryvyi Rih Professional Mining and Technology Lyceum of Dnipropetrovsk region (27 graduates), DPTNZ "Pershotravensky Mining Lyceum" of Dnipropetrovsk Region, (29 graduates), Ternovsky Professional Mining Lyceum of Dnipropetrovsk Region (56 graduates), DPT "Kyiv" (30 graduates), Bilopilsky Higher Vocational School of Sumy Region, (47 graduates), State Educational Center" Odessa Center of Vocational Education "of Odessa region (30 graduates), State Professional Lyceum of Ukrainka Kharkiv region (32 graduates), Regulations 
"Dniprorudnenskyy professional college" Zaporizhzhya region (47 graduates), Higher professional mining school (Gorishni Plavni, Poltava region (26 graduates).

Higher Education Institutions of $1^{\text {st }}$ and $2^{\text {nd }}$ levels of accreditation: Lviv State College of Food and Processing Industry of the National University of Food Technologies (47 graduates), Ivano-Frankivsk College of Restaurant Service and Tourism of the National University of Food Technologies (27 graduates), Ternopil National Technical College Ivan Puluj University (64 graduates), Zhytomyr Trade and Economic College of Kyiv National University of Trade and Economics (30 graduates), Kyiv College of Information National Aviation University (32 graduates).

In the program of ascertaining experiment a special place is occupied by our survey of employers, which involved 86 employers from 10 regions of Ukraine, which is $30 \%$ of their total number, provided an opportunity to study the structure of employment of the population of the region by types of economic activity. 7280 employees (58.8\% of the total number of employees in selected types of economic activity) work in the enterprises selected for the survey, Dnipro, Zaporizhzhya, Zhytomyr, IvanoFrankivsk, Kyiv, Lviv, Odesa, Poltava, Sumy, Ternopil region and Kyiv city.

Target groups: Group I: Entrants to educational institutions, applicants, graduates of the GV(VT)E; Group II GV(VT)E heads (directors and deputy directors, heads of departments, senior masters), representatives of regional education departments, teachers and masters of production training of GV(VT)E; III - stakeholders, representatives of local employers and businesses; local employment centers.

The survey of 175 entrants aimed to identify the motives for choosing a future profession.

According to the results of the survey, it is found that the preferred age of respondents is 16-19 years; education basic general secondary education (110 persons $(63 \%))$.

The survey identified problems related to the selection and formation of motivation for choosing professions, in particular 84 respondents (48\%) entered the vocational training institution, having learned about the chosen profession from friends, from parents and relatives -19 people $(10.9 \%)$, independently through the Internet 21 people $(12 \%)$ and from other sources - 17 people (9.7\%), and only a fifth of all interviewees received professional information from teaching staff (34 persons (19.4\%)) (fig. 3).

The possibility of quick employment attracts 97 $(55.4 \%)$ respondents in the chosen profession; 82 persons (47\%) - high salary after graduation; 56 people $(32 \%)-$ prospects for professional growth; and only 29 people $(16.5 \%)$ have the ability to work in their chosen profession (fig. 4).

At the end of the GT(VT)E 167 (95.4\%) respondents have high salary expectations, including UAH 3-5 thousand - 36 people $(21.6 \%)$; 7-9 thousand UAH 89 persons $(53.3 \%)$; 9-12 thousand UAH - 42 (25.1\%); 142 persons $(81.1 \%)$ - employment by profession; and only 21 people $(12 \%)$ expect the opportunity to continue their studies (fig. 5).

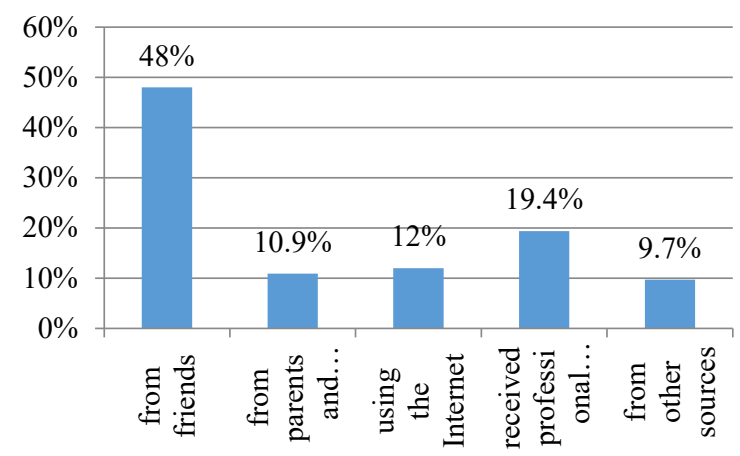

Fig. 3. Formation of motivation for choosing professions based on the results of the survey of entrants.

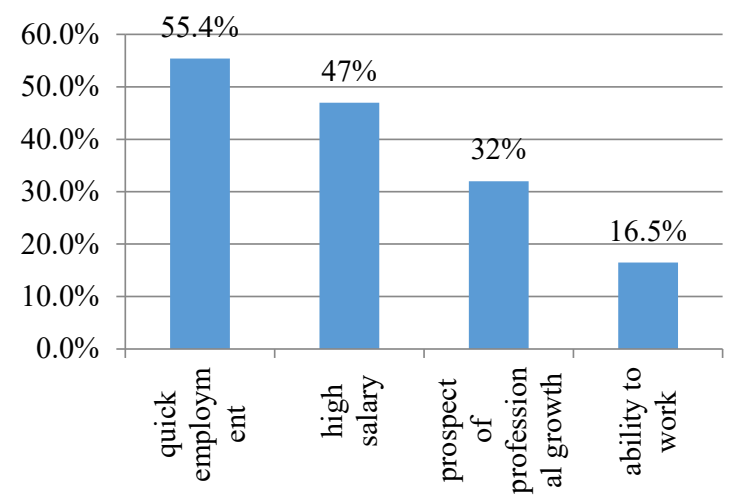

Fig. 4. Components of attractiveness of the chosen profession according to the results of the survey of entrants.

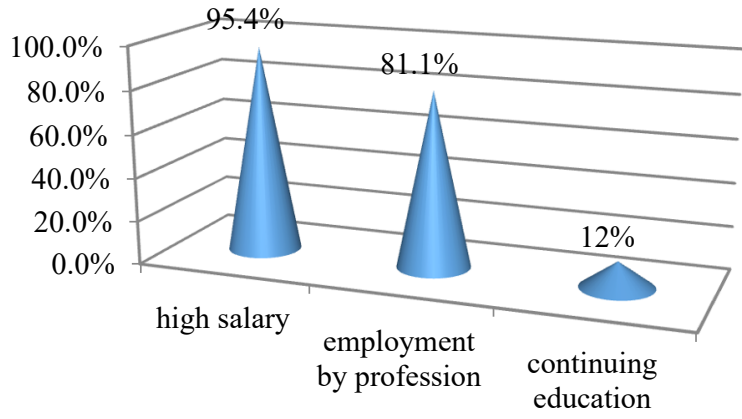

Fig. 5. Expectations of entrants after the end of the GV(VT)E (by the results of the survey).

According to the results of the survey of entrants on the first achievements after graduation, 149 (85\%) of respondents consider it necessary to have a prestigious job and 123 persons $(70,2 \%)$ to buy their own housing.

In the study of the current state of the quality of education in the GV(VT)E, 175 applicants participated, of which a considerable part (137 persons $(78.3 \%))$ state that the knowledge, skills they receive in the educational establishment are sufficient for future professional activity. $135(77 \%)$ of the interviewed interviewees believe that in 
the process of vocational training, the Lyceum staff adhere to a democratic style of communication. $45(25.7 \%)$ of the surveyed respondents said that the most attractive for them is the organizational form of conducting classes, as the speeches of pedagogical workers. Only 33 (18.8\%) respondents expressed a desire to participate in the development of various projects and their implementation. For $168(96.1 \%)$ interviewed applicants, the criteria for assessing the knowledge, skills used by teaching staff are clear.

For qualitative mastering of subjects of theoretical and theoretical training, the applicants lack the educational literature and access to the Internet (92 persons (52.6\%); Insufficient applicants consider educational support and point to the lack of multimedia training facilities (64 persons $(36.6 \%)$. The main components in preparation are the formation of professional knowledge, skills and competences necessary for competition for a job in the labor market, and the formation of the qualities necessary for self-realization in professional activity (153 persons $(87.4 \%)$.

$140(80 \%)$ of the respondents believe that pedagogical staff of the Lyceum pay due attention to the development of independent work skills; 95 (54.3\%) of applicants claim that their interests, abilities and psychological characteristics are taken into account in the training process.

All respondents noted the positive role of the use of multimedia educational facilities by pedagogical staff. Respondents state that it is possible to improve the quality of theoretical and vocational training by increasing the level of professional competence and quality of work of pedagogical staff - 49 persons $(28 \%)$ ), changes in the content of disciplines - 36 persons $(20,6 \%))$, development of a culture of communication between pedagogical employees and students - 90 people (51.4\%) and improvement of the material and technical base of GV(VT)E - 64 people (36.6\%) (fig. 6).

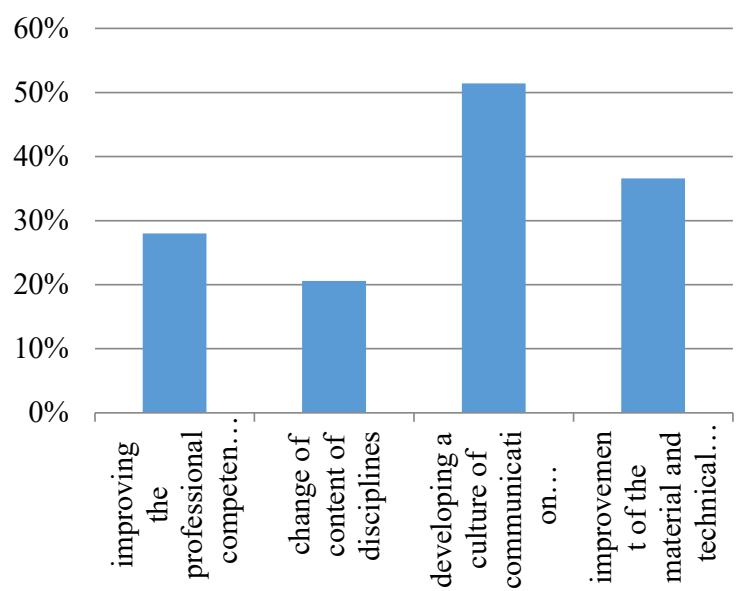

Fig. 6. Ways to increase the level of vocational training in the $\mathrm{GV}(\mathrm{VT}) \mathrm{E}$ on the results of a survey of applicants.
$135(76.9 \%)$ of the interviewed applicants recommend to the friends of the $\mathrm{GV}(\mathrm{VT}) \mathrm{E}$ for admission and further education. 280 respondents took part in the questionnaire to determine the level of professional competence and selfeducation of pedagogical staff.

Their qualitative composition is represented in the main I qualification category and 13 tariff category (fig. 7).

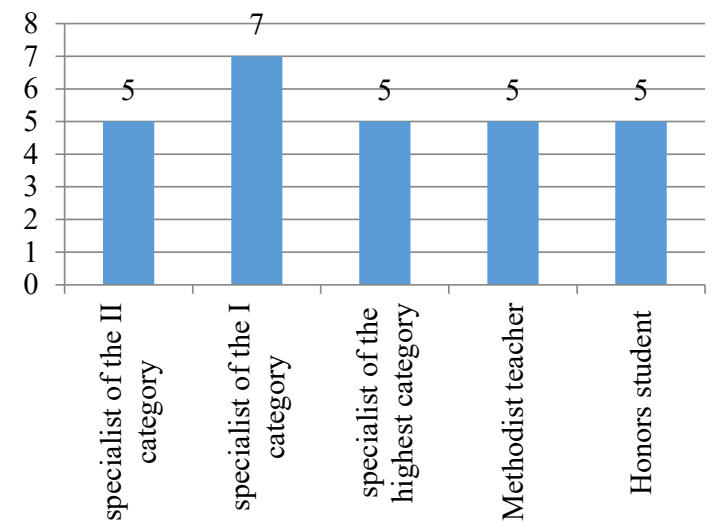

Fig. 7. Qualitative composition of teaching staff.

The study found that 210 people (75\%) had completed higher education. 85 people $(30,3 \%)$ have up to 3 years of pedagogical experience in V(VT)E; 61 persons $(21,7 \%)$ from 3 to 10 years; 61 persons $(21,7 \%)$ from 10 to 25 years; 73 persons $(26,3 \%)-25$ years and over (fig. 8 ).

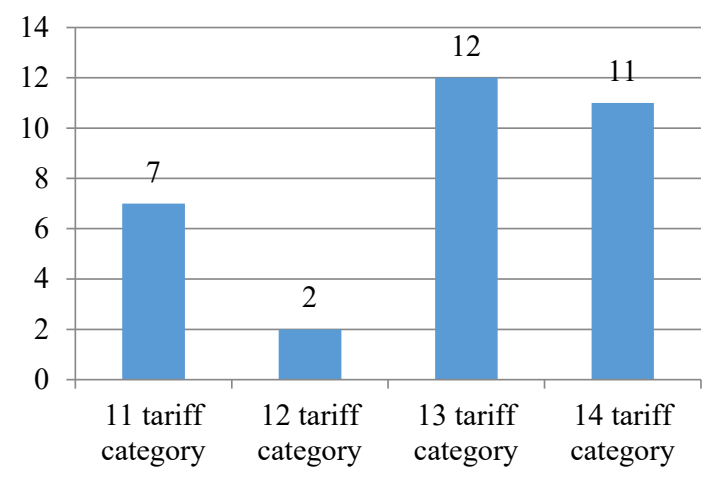

Fig. 8. Qualitative composition of masters of industrial training.

One-third of teaching staff (85 people (30.3\%) introduce innovative technologies into the educational and production process.

$210(75 \%)$ of respondents consider lack of time, $42(15 \%)$ of persons - poor awareness of innovations and only $28(10 \%)$ of persons - lack of necessary theoretical knowledge (fig. 9).

$210(75 \%)$ of employees evaluate the quality of conditions for the development of innovative activity in the educational institution as favorable, $70(25 \%)$ consider the quality of conditions satisfactory. 


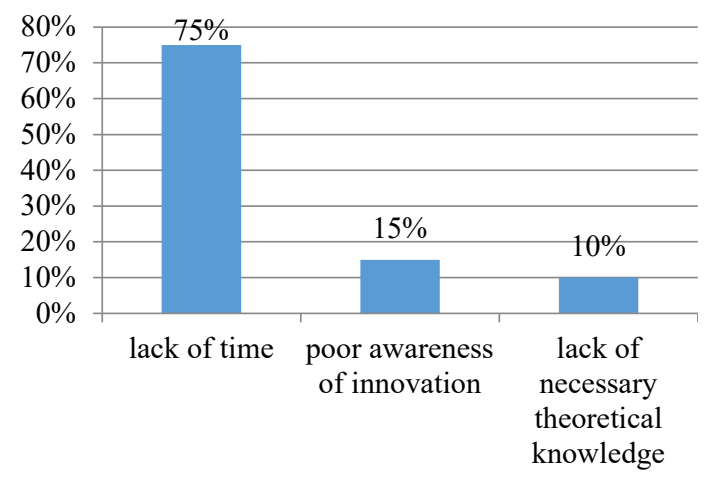

Fig. 9. Obstacles in the development of innovations by pedagogical workers and their introduction into the process of specialist training.

All pedagogical workers $(100 \%)$ carry out selfeducational activities, most of which (230 persons $(82.1 \%))$ assess their own level of readiness to study independently and acquire knowledge as average and carry out self-education occasionally, without a system.

Self-education 196 (70\%) of pedagogical workers are hampered by lack of free time, and $84(30 \%)$ lack of computer literacy and lack of necessary reference and methodological literature. Today, there are teachers who do not have computer equipment at all, and therefore do not use Internet resources in teaching activities ( 25 people $(8.9 \%))$.

$224(80 \%)$ teachers consider their own level of readiness to learn and acquire knowledge sufficient, 42 workers $(15 \%)$ consider their average level of readiness and 14 pedagogical workers $(5 \%)$ define their own level as high (fig. 10).

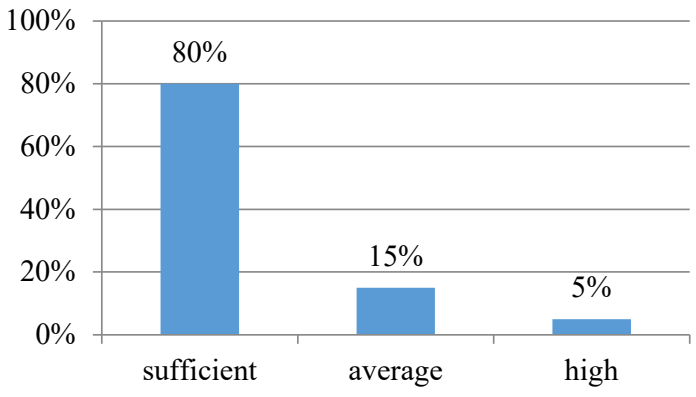

Fig. 10. Levels of readiness to study and acquire knowledge by pedagogical staff.

The most effective forms of self-education $168(60 \%)$ of pedagogical workers choose individual work (visiting libraries, studying scientific and methodical and educational literature) and participation in conferences, seminars, training courses. At the same time, 12 teachers (4.2\%) have no desire to engage in exploratory activities.

Most pedagogical workers (168 persons (60\%)) consider the level of organization of professional training of competitive specialists in their educational institution sufficient, $84(30 \%)$ believe that the level of organization of vocational training is average and only $28(10 \%)$ - high (fig. 11).

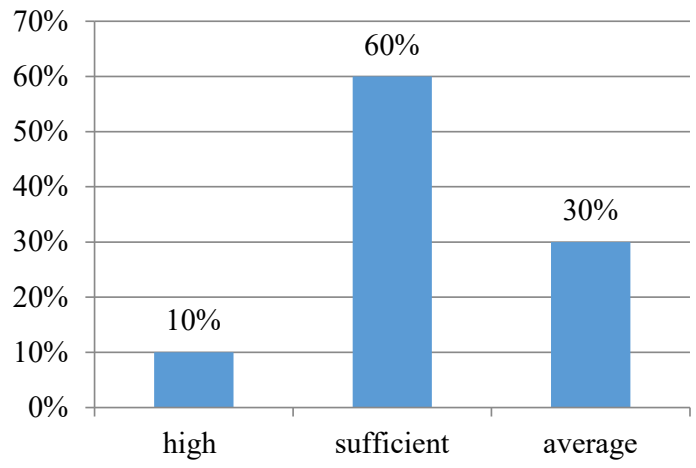

Fig. 11. Level of organization of professional training of competitive specialists (according to the survey of pedagogical staff).

During the survey of employers it was found that out of 86 enterprises $63(73 \%)$ are private, 59 enterprises $(68 \%)$ have been working for more than 10 years. At 26 enterprises $(30 \%)$, the number of employees reaches more than 500 people. 32 employers $(37 \%)$ are satisfied with the existing system of co-operation between the PA $(\mathrm{OA})$ and the enterprise in the preparation of a competitive specialist. The quality of professional training of future specialists was rated as "partially satisfactory" (68 people $(79.2 \%))$. Almost equal number of employers gave a positive assessment of the quality of training of specialists (6 people (6.9\%)) and not satisfied with the quality of training (12 people (13.9\%)) (fig. 12).

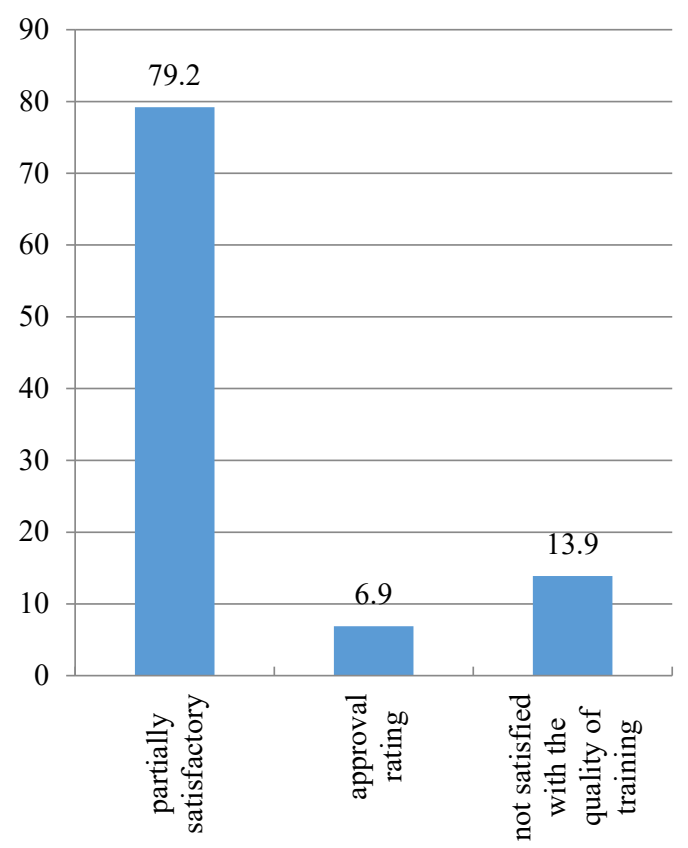

Fig. 12. Assessing the quality of professional training of a future specialist based on the results of a survey of employers 
Employers consider qualification, ability to study, responsibility, ability to work in a team, additional education or related profession, mobility as components that affect the level of a specialist's competitiveness.

The employer assesses the quality of the graduate in certain areas as high ( 5 points) $-11,1 \%$, sufficient (4 points) $62,3 \%$, medium ( 3 points) $12,2 \%$ and low $14,4 \%$ (fig. 13).

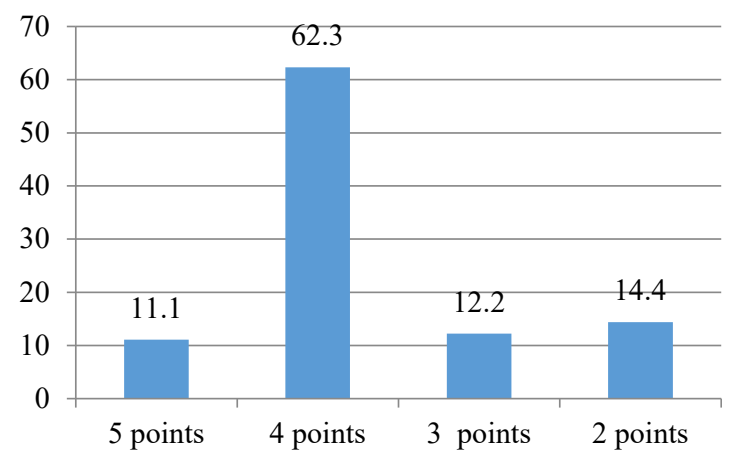

Fig. 13. Assessment of the quality of professional training of a specialist according to the directions according to the results of the survey of employers.

At the same time, employers believe that to improve the quality of training of competitive professionals it is necessary:

- to carry out internships of pedagogical workers of vocational-theoretical and vocational-practical training in the conditions of production, not once every five years, but in accordance with changes in production technologies; - to carry out internships of pedagogical workers of general education (compulsory mathematics, physics, chemistry) in real production conditions, in order to provide a professional direction in teaching;

- to adapt the State Standards of V(VT)E on the changes in production technologies.

According to the results of the survey of senior staff 84 V(VT)E About 10 regions of Ukraine, according to the program of advanced training courses (category of deputy directors of $\mathrm{GV}(\mathrm{VT}) \mathrm{E}$ on educational and production work) at the Central Institute of Postgraduate Education of the State University of Education Management of the National Academy of Pedagogical Sciences of Ukraine that the main challenges faced by the GV(VT)E is the lack of adequate training facilities, outdated equipment, or none at all (39 educational institutions (47\%). 11 (13\%) of respondents believe that the competitiveness of competitive specialists is the personal qualities of the educational acquirer (unwillingness to study, small vocabulary, etc.); Interviews with entrants are conducted as a method of qualitative selection at admission.

In the survey, 61 respondents $(73 \%)$ said that in the $\mathrm{GV}(\mathrm{VT}) \mathrm{E}$, in the professional training of future specialists, information and communication technologies and distance learning technologies are constantly used. 23 (27\%) respondents believe that cooperation with employers, international partners, holding workshops and competitions of professional skill is the most appropriate in improving the quality of training of competitive specialists.

The most common forms of social partnership in the regions are traineeships of pedagogical workers on the basis of enterprises $62(74 \%)$ respondents; introduction of elements of dual training system $11(13 \%)$; development of educational literature with the involvement of employers, conducting production training on the basis of enterprises, excursions and seminars with the participation of enterprise technologists $-11(13 \%)$ persons (fig. 14).

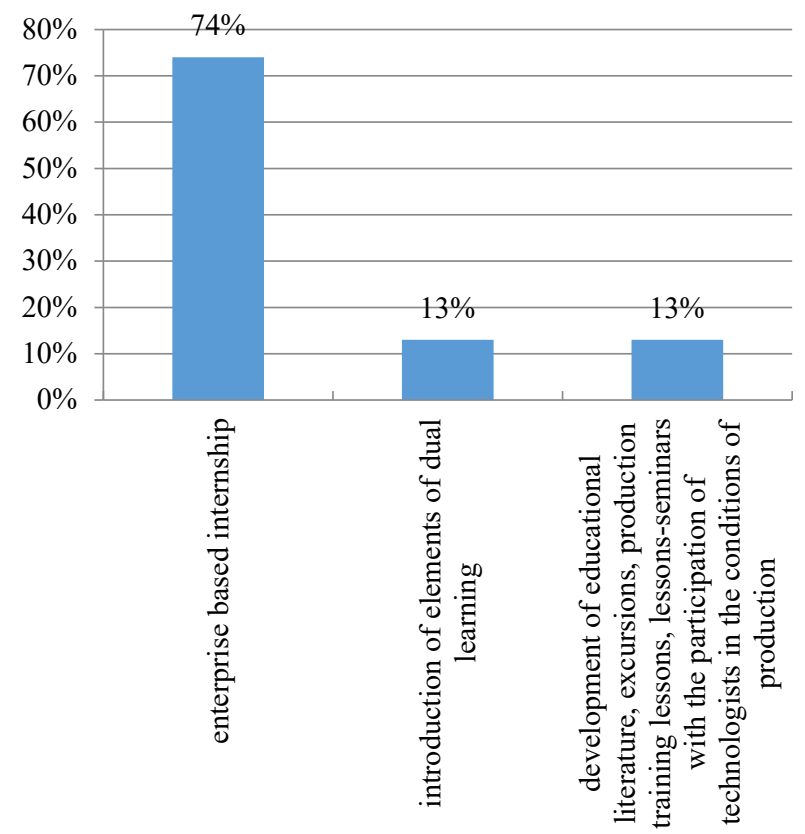

Fig. 14. Forms of social partnership of GV(VT)E and employers of different regions of Ukraine (according to the survey results).

The survey also found that $44(53 \%)$ educational institutions do not cooperate with scientific institutions, the remaining $40(47 \%)$ of the surveyed respondents cooperate with the Institute of Vocational Education of the National Academy of Pedagogical Sciences of Ukraine, the Central Institute of Postgraduate Education and the Bilotserkivsky Institute "University of Management Education", Ukrainian Engineering-Pedagogical Academy, Kharkiv Academy of Continuing Education.

$23(27 \%)$ of the surveyed GV(VT)E executives believe that the problem of training competitive professionals should be addressed at the state level, in particular by revising the State Standards of V(VT)E in accordance with the requirements of professional competences in the professions; 28 (33\%) of the respondents consider that the updating of the educational and material and technical base is the most effective tool in the training of competitive specialists; $17(20 \%)$ of the respondents indicate the need to increase the professional competence of teaching staff; $17(20 \%)$ refused the answer (fig. 15). 


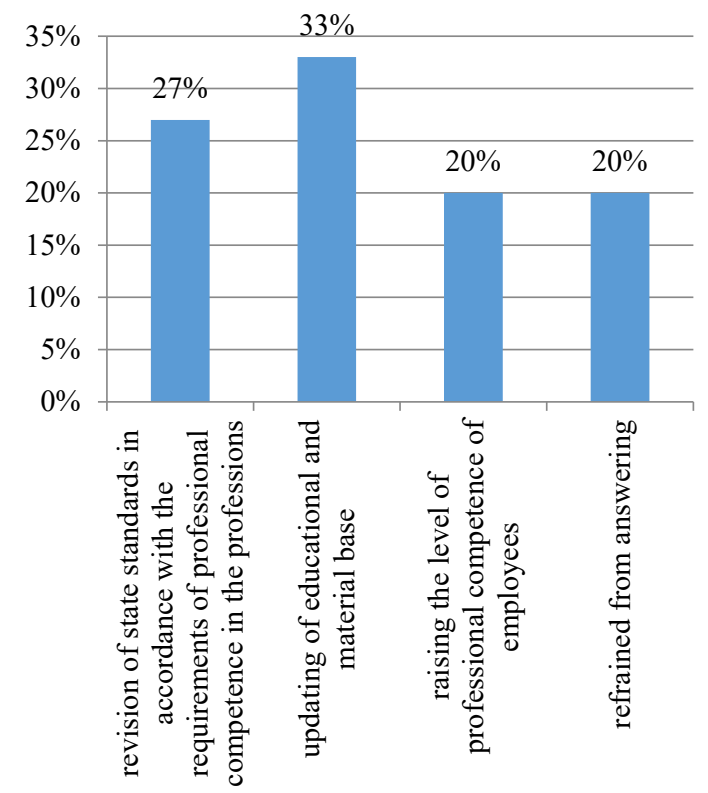

Fig. 15. Ways to Improve the Training of Competent Professionals of GV(VT)E.

\section{Conclusions and prospects for further research}

In the course of the theoretical analysis we have come to the conclusion that the concept of "competitiveness" is considered as the ability of a specialist to compete, that is, he has the appropriate competencies and personal preferences that allow to win the competition.

The main factor in ensuring competitiveness is the quality of education, which is defined as the social ideal of human education; as a result of her educational activities; as a process of organizing education and training; as an effective criterion for the functioning of the educational system.

The results of this study are a pedagogical experiment, in which the quality and effectiveness of V(VT)E in the following areas were determined: the content of vocational training and its comprehensive methodological support; motivation and availability of V(VT)E; professional success of graduates; personnel potential of educational institution; material-technical base.

The survey conducted by the author's questionnaires gives grounds to claim that the majority of the graduates of the GT(VT)E have developed a satisfactory level of satisfaction with professional training; according to employers, the content of vocational training programs needs significant changes; teaching staff do not have experience in the manufacturing sector; lack of funding and an outdated material base remains a problem.

This article aims to realize the idea (prospect of further research) of improving the quality of education, capable of ensuring a high level of competitiveness of specialists, by creating a holistic system of cultural content that will cover the balanced development of the mental, emotional, value, volitional and physical spheres.

\section{References}

1. P. Sauh, Alhorytm realizatsii Ya-kontseptsii osobystosti $u$ protsesi profesiinoho samovyznachennia (An algorithm for realizing the self-concept of personality in the process of professional self-determination). Yakontseptsiia akademika Nelli Nychkalo u vymiri profesiinoho rozvytku osobystosti (The self-concept of Academician Nelly Nichcalo in measuring the professional development of the individual). (Instytut pedahohichnoi osvity i osvity doroslykh NAPN Ukrainy, Kyiv, 2014), pp. 62-69

2. Proekt kontseptualnykh zasad reformuvannia profesiinoi osvity Ukrainy "Suchasna profesiina osvita" (Draft Conceptual Framework for the Reform of Vocational Education in Ukraine "Contemporary Vocational Education") (2019), https://mon.gov.ua/ua/news/mon-rozrobilo-proektkonceptualnih-zasad-reformuvannya-profesijnoyiosviti-ukrayini-suchasna-profesijna-osvita. Accessed 20 Dec 2019

3. B.M. Bim-Bad, Pedagogiko-antropologicheskoe osnovanie teorii i praktiki sovremennogo obrazovaniia (Pedagogical and anthropological basis of the theory and practice of modern education). http://www.bimbad.ru/biblioteka/article_full.php?aid=95. Accessed 20 Dec 2019

4. Kontseptsiia realizatsii derzhavnoi polityky u sferi profesiinoi (profesiino-tekhnichnoi) osvity "Suchasna profesiina (profesiino-tekhnichna) osvita" na period do 2027 roku (The concept of state policy in the field of vocational (vocational-technical) education "Modern vocational (vocational-technical) education" for the $\begin{array}{llll}\text { period up } & \text { 2027) }\end{array}$ https://zakon.rada.gov.ua/laws/show/419-2019-

\%D1\%80\#n8. Accessed 20 Dec 2019

5. G.O. Kozlakova (ed.), Kontseptualni zasady psykholoho-pedahohichnoi pidhotovky konkurentozdatnoho fakhivtsia $v$ umovakh pisliadyplomnoi pedahohichnoi osvity: na vybirtsi naukovo-pedahohichnykh pratsivnykiv (Conceptual bases of psychological and pedagogical training of competitive specialist in the conditions of postgraduate pedagogical education: on a sample of scientific and pedagogical workers). (Universytet menedzhmentu osvity, Kyiv, 2015), p. 40

6. A.G. Romanovsky, O.S Ponomaryov (ed.), Rozvytok liderskoho potentsialu natsionalnoi humanitarnotekhnichnoi ta upravlinskoi elity (Development of the leadership potential of the national humanitariantechnical and administrative elite). (Politekhnichnyi instytut, Kharkiv, 2017), p. 290

7. S.V.Smirnov, Dissertation, Pivdennoukrainskyi natsionalnyi pedahohichnyi universytet im. K.D. Ushynskoho, 2018 
8. L.A. Dudko, Dissertation, Instytut sotsiolohii, 2004

9. E.L. Kholodtseva, Osobennosti podgotovki spetcialistov, konkurentosposobnykh na rynke truda (Features of training specialists competitive in the labor market). Sbornik trudov studentov i molodykh uchenykh Kemerovskogo gosudarstvennogo universiteta (Collection of works of students and young scientists of Kemerovo State University). (Poligraf, Kemerovo, 2004), pp. 88-90

10. S.N. Shirobokov, Dissertation, Omskii gosudarstvennyi pedagogicheskii universitet, 2000

11. R.A. Fathutdinov, Globalnaia konkurentosposobnost (Global competitiveness). (Ekonomika, Moscow, 2009)

12. T.Y. Andriyako, Pedahohichna sutnist i struktura konkurentospromozhnosti fakhivtsia (Pedagogical essence and structure of specialist competitiveness). Visnyk Cherkaskoho universytetu 189(2), 116 (2010)

13. A. Ansoff, Strategicheskoe upravlenie (Strategic Management). (Ekonomika, Moscow, 1989)

14. E.A Klimov, O stanovlenii professionala: priblizhenie $k$ idealam kultury $i$ sotvorenie ikh (psikhologicheskii vzgliad) (On becoming a professional: approaching to the ideals of culture and their creation (psychological view)). (IPPS, Moskva, 2006)

15. L.M. Mitina, Psikhologiia razvitiia konkurentosposobnoi lichnosti (Psychology of competitive personality development). (Voronezh, Moskovskii psikhologo-sotcialnyi institut, 2002)

16. T.A. Slivina, Dissertation, Sibirskii gosudarstvennii universitet, 2008

17. O.A. Fil, Dissertation, Instytut psykholohii im. H. S. Kostiuka APN Ukrainy, 2006

18. I.P. Sarattseva, Dissertation, Dalnevostochnyi gosudarstvennyi universitet putei i soobshchenii, 2005

19. S.A. Hazova, Dissertation, Adygeiskii gosudarstvennyi universitet, 2011

20. A. Adcroft, J. Teckma, R. Willis, International Journal of Public Sector Management 23 (6), 588 (2019)

21. A.R. Bakar, I. Hanafi, Assessing employability skills of technical-vocational students in Malaysia. J. Soc. Sci 3, 202-207 (2007)

22. R. Viederyte, Globalization influence on competitive education and knowledge spreading activity. Economics \& Management 14, 1032-1036 (2009)

23. Three elephants of vocational education. UGP Education Expert Group (2019), http://educationua.org/images/uploads/285/00012.png. Accessed 20 Dec 2019

24. Europa 2020, Strategia na rzecz inteligentnego i zrównoważonego rozwoju sprzyjającego włączeniu społecznemu (Komunikat Komisji, Bruksela, 2010), https://ec.europa.eu/eu2020/pdf/1_PL_ACT_part1_v1. pdf. Accessed 20 Dec 2019

25. V.G. Viktorov, Dissertation, Instytut vyshchoi osvity APN Ukrainy, 2006
26. S. Slade, What Do We Mean by a Quality Education? (2017), https://www.huffpost.com/entry/what-do-wemean-by-a-qual_b_9284130. Accessed 20 Dec 2019

27. L.M. Sergeeva (ed.), Upravlinnia rozvytkom profesiino-tekhnichnoho navchalnoho zakladu: teoriia $i$ metodyka (Development Management of a Professional School: theory and methodology). (Lira-K, Kyiv, 2017)

28. V.V. Rybalka, Profesiinyi rozvytok (Professional development), in Entsyklopediia osvity. (Yurincom Inter, Kyiv, 2008)

29. A.P. Belyaeva (ed.), Prognosticheskie $i$ metodologicheskie funktcii pedagogicheskogo eksperimenta. Organizatciia $i$ provedenie pedagogicheskogo eksperimenta $v$ uchebnykh zavedeniiakh. (Prognostic and methodological functions of pedagogical experiment. Organization and conduct of pedagogical experiment in vocational education institutions). (Editus, Saint Petersburg, 1992) 